\title{
Sport Coaches Learn to Coach in Hong Kong
}

\author{
Alberto Cruz \\ Department of Health and Physical Education, the Education University of Hong Kong, Hong Kong, China \\ Email: acruz@eduhk.hk
}

How to cite this paper: Cruz, A. (2017).

Sport Coaches Learn to Coach in Hong Kong. Advances in Physical Education, 7, 425-443.

https://doi.org/10.4236/ape.2017.74036

Received: September 25, 2017

Accepted: November 7, 2017

Published: November 10, 2017

Copyright (C) 2017 by author and Scientific Research Publishing Inc. This work is licensed under the Creative Commons Attribution International License (CC BY 4.0).

http://creativecommons.org/licenses/by/4.0/ (c) (i) Open Access

\begin{abstract}
Sport coaching is dynamic and complex. Sport coaches must develop a range of skills and knowledge to coach competently. Studies have shown that school sport coaches learn to coach through many different situations. School sport coaches seem to learn to coach through life experiences in various learning situations. To date, few studies have investigated the process by which school sport coaches in Hong Kong learn how to coach. Therefore, the present study examined the learning situations in which school sport coaches learn to coach and the factors that influence their coaching practice, using Moon's generic view of learning. Twelve sport coaches with a minimum of one year's experience of coaching in schools were recruited in this study. Snowball sampling was employed to maximise variation of the sample. Two semistructured interviews were conducted to gather information concerning their sporting experiences, career paths, learning-to-coach processes, and coaching practice in schools. Deductive content analysis was used to organise and categorise the data. The trustworthiness of the study was established using peer debriefing and member checking. Findings indicated that school sport coaches learn to coach through formal coaching education courses and informal learning settings: mentoring and exchanging ideas with other coaches and physical education teachers. Sport coaches also reported that their past sporting and coaching experience helped their coaching practice. Number of participants, school equipment and facilities, and weather were major factors that influence the practice of school sport coaches. The findings of the study have implications for the training of sport coaches with respect to their specific learning needs and knowledge of how to coach in Hong Kong's school system. Learning strategies should be provided to address different learning situations coaches might encounter and the factors that influence practice to facilitate their coaching in schools.
\end{abstract}

\section{Keywords}

School Sport Coaches, Coaching, Learning Situations 


\section{Introduction}

As school sport activities gain popularity and primary and secondary schools increasingly participate in interschool competitions, the number of student athletes and school sport teams at each school has increased in recent years in Hong Kong. As in other countries, school physical education (PE) teachers were formerly the primary person working with student athletes in schools (Ha, Hums, \& Greenwell, 2011; Spencer, 1999). To provide coaching to school teams and supervise sport activities, some primary and secondary schools have begun to assign classroom teachers and recruit sport coaches to serve as coaches to supervise these extracurricular activities. Although some classroom teachers may have had some experience in the sport, either as an athlete or as a coach, some may only have been recreational players. Because of this increasing trend, school PE teachers and classroom teachers are often required to coach multiple sports-including sports with which they are unfamiliar-because of a lack of available coaches (Lacroix, Camiré, \& Trudel, 2008). Some coaches encounter challenges when coaching because of their unfamiliarity with a certain sport and must learn and familiarise themselves with current coaching knowledge and practices.

School sport coaches work within the developmental-level sport context that is characterised by increased commitment from coaches and athletes (Trudel \& Gilbert, 2006). They are believed to have different learning needs compared with developmental coaches who work outside of the school context. The major difference between the learning of school sport coaches and that of other developmental-level coaches is related to formal learning situations, that is, the differences in the coaching education programmes that they undertake. Most developmental-level coaches in Hong Kong are required to obtain qualified coaching status from the National Sports Associations. By contrast, school coaches can coach school sports without qualified coaching status. Although the Hong Kong Coaching Committee has developed training programmes for school sport coaches, school coaches are not obliged to attend training programmes before coaching in schools. Moreover, most developmental sport coaches participate for several years as competitive athletes in the sport they coach, which provides them with informal knowledge concerning a coach's role (Sage, 1989; Trudel \& Gilbert, 2006). Novice school sport coaches often differ from developmental sports coaches when they start their teaching careers because they are asked to coach a sport with which they are unfamiliar, in which they have no prior athletic or coaching experience (Lacroix et al., 2008). They usually coach with relatively few guidelines and are expected to perform to the level of their more experienced colleagues (Bell, 1997). Level of coaching ability, athletic experience, and overall sporting knowledge influence school coaches' planning and ultimately affect their capability to provide a suitable learning environment for student-athlete development. Given these circumstances, school sport coaches may have certain learning needs that differ from those of other developmental sport 
coaches. The present study was conducted to more profoundly understand school sport coaches' learning processes as they learn to coach in Hong Kong.

In recent years, coaching researchers have examined how developmental- and recreational-level coaches learn to coach; both types of coach may have specific learning needs in their coaching contexts (Lemyre, Trudel, \& Durand-Bush, 2007; Winchester, Culver, \& Camiré, 2013). Kirk (2010) reported that the school sport context differs from community sport contexts because "schools do more than teach sport". After an extensive review of the literature on coaching and coach education, Trudel and Gilbert (2006) concluded that coaches learn to coach through coach education programmes and experience. Researchers have determined that sport coaches learn to coach through several situations (including playing experience, mentoring, coaching courses, conferences, interactions with other coaches, and online resources) (Erickson, Bruner, Macdonald, \& Côté, 2008; Irwin, Hanton, \& Kerwin, 2004; Jones, Armour, \& Potrac, 2003; Pope, Stewart, Law, Hall, Gregg, \& Robertson, 2014; Winchester et al., 2013; Wright, Trudel, \& Culver, 2007). However, numerous studies have indicated that formalised learning venues are not valued by coaches as much as their daily learning experiences on the sports field. Sport coaches seemingly spend more time learning to coach in a less formal environment (Gilbert, Côté, \& Mallett, 2006). Researchers have also reported that the approaches through which sport coaches learn to coach may vary from coach to coach (Gilbert \& Trudel, 2005; Trudel \& Gilbert, 2006; Wright et al., 2007). Therefore, we must develop an individualised approach to understand how school sport coaches develop knowledge. Thus, in this study we adopted Moon's $(1999 ; 2004)$ generic view of learning to understand how school sport coaches learn to coach.

\section{Theoretical Framework}

Moon $(2001 ; 2004)$ has proposed a constructivist view of learning in which the emphasis is placed on the learner and how the learner constructs knowledge within a social context. Moon's ideas have been used in coach development studies (Trudel, Culver, \& Werthner, 2013; Werthner \& Trudel, 2006) and were suggested as future directions for studying coaching (Carter \& Bloom, 2009). Central to Moon's $(1999 ; 2001 ; 2004)$ generic view of learning are two categories of learning approach (surface learning and deep learning) that collectively encompass five stages of learning: noticing, making sense, making meaning, working with meaning, and transformative learning. Moon further used the terms "building a brick wall" and "network" to explain her views concerning learning. From the viewpoint of building a brick wall, the instructor helps the learner to construct the "bricks of knowledge" by providing information. The instructor is assumed to know how these bricks build the wall; the instructor develops this component of knowledge. Learning is linear and no learning occurs without learning the bricks. When applied to coach education programmes, it means that sport associations or organisations mandate experts and programme designers 
to develop courses in terms of content knowledge (the brick wall), delivery format, and assessment tools. Course providers are then trained to teach the content. The role of coaches in learning is relatively passive because they are expected to receive specific information and reproduce it when assessed. Certification is awarded to those who obtain predetermined success marks, and the coaches are assumed to transfer this learnt knowledge to their own sport setting. However, this type of learning may not be effective because of the different needs and profiles of the coaches (Cushion, Armour, \& Jones, 2003; Gilbert et al., 2006; Lemyre \& Trudel, 2004; Wright et al., 2007). Moon (2004: 16) then used "the network" to describe her second view of learning as "a vast but flexible network of ideas and feelings with groups of more tightly associated linked ideas/feelings". Learning may occur in many different processes with diverse individuals or parties every day. The network of the knowledge and feelings of the learner may change the cognitive structure and represent what the learner learns at any one particular point in time. Learning is viewed as a process of changing conceptions (the cognitive structure). The cognitive structure plays a crucial role in the learning process by guiding what we choose to pay attention to or what we choose to learn.

Werthner and Trudel (2006) conducted a case study on elite level coaches by applying Moon's theory of learning to the coach's learning process. The coach's cognitive structure is at the centre of this theory; the coach's cognitive structures changes and adapts under the influences of three types of learning situations: mediated, unmediated, and internal. Werthner and Trudel (2006) suggested that the mediated learning situations regroup all the formal and less formal learning situations, such as formalised coaching courses and workshops. The learning is directed by another person and the learner has no or little control over the material of teaching; the unmediated learning situations are the informal or incidental learning situations, such as a coach who decides to search for drills online. Learning situations occur when no instructor is present and the learner decides what to learn. In these situations, the learner controls the learning material. The third learning situation, the internal learning situation, refers to the process of reflection without necessarily considering external new material. It occurs when no new material is introduced. Rather, a reconsideration or reorganisation of current knowledge occurs to create new knowledge. In all learning situations, the learner produces and reproduces knowledge which depends on the interplay between the learner and instructor provided within the learning process. In other words, many educational opportunities facilitate coach learning and development. Recently, a study of school sport coaches in Hong Kong determined that the coaches developed and updated their coaching knowledge through various informal learning situations (Cruz, Li, \& Kam, 2009).

Researching the diverse learning situations of school sport coaches furthers understanding of school sport coaches' development. Studies have reported that sport coaches learn to coach through many different situations (Winchester et 
al., 2013; Wright et al., 2007). Research findings also indicated that Hong Kong school sport coaches learn to coach through both formal and informal learning situations (Cruz, 2014). School sport coaches seemingly learn to coach through life experiences in various learning situations. To date, a limited number of studies have investigated the processes by which school sport coaches in Hong Kong learn to coach. Therefore, this study examined the learning situations in which school sport coaches learn to coach and the factors that influence their coaching practice, using Moon's generic view of learning (Moon, 2004). This study also explored the school sport coaches' perceptions and the adequacy of their coach education programmes with reference to their coaching practice in schools. This information is invaluable to coach educators because the findings may help to improve existing coach education programmes in Hong Kong. The results also have implications for the preparation of novice school sport coaches for coaching in school contexts. The findings of the study are expected to benefit coach educators by helping them further understand the process of learning to coach among Hong Kong's school sport coaches and help them to design more effective coach education programmes that address the specific learning needs of school sport coaches.

\section{Methods}

To understand the learning process, participants should be involved to discuss their own learning (Jarvis, 2006). Semistructured interviews were used to uncover the lifelong learning situations of school sport coaches. School sport coaches with a minimum of 1 year's experience of coaching in Hong Kong schools were targeted to be participants in the study. The invited coaches were involved in coaching individual or team sports either in primary or secondary schools. The participants were recruited after ethical approval was granted by the University Research Ethics Committee. Participants were 12 school sport coaches (eight males, four females) between the ages of 22 and 33 years $(M=$ $25.67, \mathrm{SD}=3.34$ ) across a variety of team and individual sports who have achieved the elementary or level one National Sport Coaching Certificate. The coaching experience of participants ranged from 2 to 18 years $(\mathrm{M}=6.67, \mathrm{SD}=$ 4.46). The sport playing experience of participants ranged from 8 to 20 years $(\mathrm{M}=$ $14.08, \mathrm{SD}=4.59)$. Educationally, one had a master's degree, one had an undergraduate degree, and the others were student teachers studying bachelor of education programme majors in PE when they participated in the study. The description of the participants at the time of the study is shown in Table 1 . The school coaches were recruited through emails sent to school PE teachers in charge of hiring sport coaches and assigning other teachers to coach duties for school sports in their schools. The purpose of the study was explained in the email. Interested sport coaches responding to the researcher organised a time and place convenient for conducting interviews. Snowball sampling was also employed to maximise variation of the sample (Creswell, 2007; Miles \& 
Table 1. Description of participants.

\begin{tabular}{|c|c|c|c|c|c|c|}
\hline Pseudonym & Gender & $\begin{array}{l}\text { Age } \\
\text { (Yrs) }\end{array}$ & Sport & $\begin{array}{c}\text { Coaching } \\
\text { experience } \\
\text { (Yrs) }\end{array}$ & $\begin{array}{c}\text { Playing } \\
\text { experience } \\
\text { (Yrs) }\end{array}$ & Education \\
\hline Adam & M & 33 & Rugby & 11 & 20 & Master degree \\
\hline Ben & M & 22 & Soccer & 2 & 12 & $\begin{array}{c}\text { BEd (PE) } \\
\text { Yr } 3 \text { student }\end{array}$ \\
\hline Cathy & $\mathrm{F}$ & 32 & Netball & 18 & 25 & $\begin{array}{c}\text { Undergraduate } \\
\text { degree }\end{array}$ \\
\hline Dick & M & 24 & Basketball & 4 & 15 & $\begin{array}{c}\text { BEd (PE) } \\
\text { Yr } 4 \text { student }\end{array}$ \\
\hline Eaton & M & 24 & Handball & 6 & 15 & $\begin{array}{c}\text { BEd (PE) } \\
\text { Yr } 4 \text { student }\end{array}$ \\
\hline Fred & M & 25 & Athletic & 5 & 10 & $\begin{array}{c}\text { BEd (PE) } \\
\text { Yr } 4 \text { student }\end{array}$ \\
\hline Garry & M & 25 & Athletic & 5 & 10 & $\begin{array}{c}\text { BEd (PE) } \\
\text { Yr } 3 \text { student }\end{array}$ \\
\hline Helen & $\mathrm{F}$ & 24 & $\begin{array}{c}\text { Rope } \\
\text { skipping }\end{array}$ & 2 & 8 & $\begin{array}{c}\text { BEd (PE) } \\
\text { Yr } 2 \text { student }\end{array}$ \\
\hline Ivan & M & 26 & Handball & 6 & 15 & $\begin{array}{c}\text { BEd (PE) } \\
\text { Yr } 4 \text { student }\end{array}$ \\
\hline Jane & $\mathrm{F}$ & 24 & $\begin{array}{c}\text { Rope } \\
\text { skipping }\end{array}$ & 6 & 10 & $\begin{array}{c}\text { BEd (PE) } \\
\text { Yr } 4 \text { student }\end{array}$ \\
\hline Karen & F & 24 & Athletic & 5 & 16 & $\begin{array}{c}\text { BEd (PE) } \\
\text { Yr } 4 \text { student }\end{array}$ \\
\hline Lacy & M & 24 & Swimming & 10 & 13 & $\begin{array}{c}\text { BEd (PE) } \\
\text { Yr } 4 \text { student }\end{array}$ \\
\hline
\end{tabular}

Huberman, 2014). The participants were identified by people who knew other people with case-specific rich information. A pilot study was administered to two coaches to validate the two interview guides before the beginning of the investigation. Following the first interview, the sport coaches were asked if they knew any other potential participants. These potential participants were also invited to participate in the study.

Two semistructured interviews were conducted with each participant to uncover information related to their sport experiences, career paths, processes of learning to coach, and coaching practices in school. During the first interview, the participants were asked to describe their previous sport experiences and coaching careers. The interview consisted of specific questions regarding demographic information, the number of years they had played or coached sports, their coaching certification level, and how they had become school sports coaches. On the basis of analysis of the information collected in the first interview, the investigator prepared questions for the second interview. During the 
second interview, the investigator asked questions to obtain additional details on aspects that had been mentioned in the first interview and information on the participants' overall coaching experience. The rest of the interview included questions about how they had learnt to coach, the challenges faced in coaching, how they handled these difficulties, and approaches for making the coaching process easier. Probing questions were used throughout the interviews to obtain detailed information from the participants. The first interview lasted approximately half an hour, whereas the second interview took approximately $30-45$ minutes. All interviews were audio taped to ensure accuracy in data collection. Interviews were conducted in Chinese. After each interview, the data were immediately transcribed and translated into English to maintain the validity of the research and to guarantee data quality (Patton, 2002). The interview scripts were verified by the investigator to ensure that all expressions and responses from the participants or translator were accurately presented.

\section{Data Analysis}

All interview data were transcribed verbatim in Microsoft Word and saved in rich text format for further data analysis using Nvivo (Version 8) software. Nvivo helped the investigator to analyse the scripts and identify categories, themes, and supporting quotes. Data were coded according to the key questions responded to by the participants during the interviews, resulting in the creation of the coding categories (nodes) for learning coaching, perception of coach education, and difficulties faced. Each question was then coded to identify and quantify the range of responses given in answer to the questions, and categories (nodes) were created for each of the themes that emerged from the analysis. The themes were then reviewed using a systematic process, seeking connections between the themes and their relevance to the study objectives. In the latter stage, themes were refined by reviewing the content and associations between themes (Braun \& Clarke, 2006). Deductive content analysis (Patton, 2002) was used to analyse and identify meaningful information composing the comprehensive text segment. The interview transcripts were read and passages from each interview that addressed the same topic were regrouped under a category. The categories were based on a review of the literature (Gilbert \& Trudel, 2001; Winchester et al., 2013; Wright et al., 2007) and Moon's theoretical framework (Moon, 2004). The analysis was mostly deductive given that the literature on the learning situations of coaches and the factors involved in the learning process originated from Moon's (2004) generic view of learning. The categories were grouped into themes labelled learning situations and factors affecting coaching practices. The trustworthiness of the study was established through peer debriefing (Creswell, 2007) and member checking (Merriam, 2009). The coding process was discussed at different times with a peer familiar with and knowledgeable about sport coach learning. The member check was performed at the beginning of each second interview to verify the data's accuracy and interpretation. Pseudonyms were used 
to ensure the anonymity of the participants.

\section{Results}

This study examined how school sport coaches learn to coach and the factors that influence their coaching practices. The findings are presented in terms of learning settings and factors affecting coaching, as reported by the school coaches; these settings and factors were developed through the data analysis.

\subsection{How Did the School Sport Coaches Learn to Coach in Schools?}

School sport coaches reported that they learnt to coach through formal coach education courses and informal learning settings: observing other coaches, mentoring, playing sports, exchanging ideas with other coaches and PE teachers, and learning in related university degree programmes.

\subsubsection{Formal Coach Education Courses}

The participants considered completing coaching courses organised by the $\mathrm{Na}$ tional Sport Associations as vital for learning to coach sport in schools. The coaching courses helped to improve their ability to coach. Attending formal coach education programmes enhanced their coaching knowledge and confidence in school practice. Some commented that the coaching methods taught during the programme were useful and assisted them to design coaching sessions and establish teaching procedures for skill-learning activities. They were satisfied with the coaching courses attended and believed that they were sufficiently equipped to be sport coaches in school.

I am happy having attended the coaching course [...] the tutors provided basic coaching knowledge and related skill-learning procedures to us. It is worthwhile attending the course [...] (Adam, Interview 1).

I expect to learn how to deliver coaching sessions in the coaching course [...] the coaching course has enhanced my coaching and planning knowledge in conducting coaching sessions. I am more confident to coach after taking the course [...] (Gary, Interview 1).

\subsubsection{Informal Learning Settings}

The participants mentioned that they also learnt to coach through several learning situations in addition to attending formal coaching courses. These learning situations are based on personal experience and activity connected to the sports of the participants.

1) Observing Other Coaches

Observing other coaches delivering coaching practice is a straightforward approach to learning to coach. Most participants in the study reported that they initially learnt to coach through informally watching how other coaches operated. Learning through observing the practices of other coaches improved their coaching proficiency. Most admitted that they started to learn coaching practice from their head coaches and other coaches in their field. 
[...] planning and coaching in schools is not easy. I learnt a lot of ideas by observing other school coaches delivering their practice. I started coaching by adopting their coaching activities into my coaching sessions [...] (Fred, Interview 1).

[...] I did not know how to plan and coach in school originally, I learnt some coaching skills and training practices by watching and analysing other coaches delivery [...] I learnt a lot by just watching other coaches [...] (Ivan, Interview 1).

2) Formal Mentoring

Mentoring was available for some coaches in the present study. Some National Sport Associations had provided formal mentoring opportunities for novice coaches to familiarise themselves with the coaching process. Senior experienced coaches were assigned to the novice coaches when they started coaching. A quarter of coaches reported that mentorship was the most crucial aspect in learning to coach. Some participants claimed that they had learnt and benefited from this arrangement and understood the roles and coaching practices from their mentors. Slightly more than half of the respondents agreed that mentorship could facilitate their learning to coach.

[...] I learnt how to coach when I was an assistant coach [...] Mentoring is very important. This helped me understand the practice of coaching. I observed and learnt from an experienced coach in a real situation [...] (Helen, Interview $1)$.

[...] I would ask the experienced coach questions about his coaching practices. He gave me constructive advice for my coaching performance. I benefited from this mentoring system when learning to coach [...] (Jane, Interview 1).

3) Playing and Coaching Experience

Personal experience in playing and coaching sport were mentioned by several participants as helpful in their development as sport coaches. Three quarters of the respondents agreed that experience of sport participation and competition was crucial to sport coaching. They reported that sport and coaching experiences helped them more thoroughly understand the sport, the learning needs of players, and coaching practice. Past playing and the accumulation of coaching experiences influenced their coaching philosophy and practices.

[...] my sport playing and coaching experience makes me understand more about the skill-learning and tactical knowledge. These experiences help me know how to assist the players to learn the sport [...] (Cathy, Interview 2).

[...] having much experience in playing handball definitely helps my coaching practice. I can share my playing experience with the players and enhance their learning $[. .$.$] past coaching experience also improves and refines my coaching$ practice [...] (Eaton, Interview 2).

4) Interactions with Other Coaches/PE Teachers

Most participants reported that informal interactions with other coaches and school PE teachers were key sources of learning and development. They learnt when they worked with other experienced coaches and school PE teachers. 
Nearly all coaches responded positively to interactions with other school coaches and school PE teachers. They generally agreed that these interactions were beneficial to coaching practice when exchanging views on practice and coaching experience. Half of the coaches said interactions with other coaches were a key aspect of learning to coach.

[...] to me the best way to learn was always through interactions with others. I learnt a lot from the people I worked with. Through discussion I understand how they coach and more about coaching [...] (Lacy, Interview 2).

[...] talking to school PE teachers helped me understand the players more. They also shared their ways of handling and teaching students. I learnt new ideas of treating players in coaching sessions [...] (Dick, Interview 2).

5) Sport-Related University Programme

Most of the participants in the present study were student teachers in PE teacher education programmes. They reported that they learnt principles for teaching sport skills and coaching knowledge in their PE teacher education programme. They commented that they benefited from the programme and that the coaching knowledge was useful to their coaching practice in schools. The coaches gained their coaching knowledge from participating in sport-related academic programmes through personal development.

[...] I apply what I learnt in the PETE programme to my coaching practice. The course concerning teaching methods in PE helps me how to plan coaching activity [...] (Ben, Interview 2).

$[\ldots]$ the motor learning and teaching principles that I learnt in my PETE programme help my coaching. This knowledge is vital and useful when I coach skipping rope at school [...] (Jane, Interview 2).

\subsection{What Are the Factors Influencing the Coaching of School Sport Coaches in Schools?}

School sport coaches reported that the coaching practiced in schools was not without difficulties. They faced a number of problems when coaching in a school context. The number of participants, school equipment and facilities, attitudes of learners, and weather were identified as major contextual factors influencing in-school practice.

\subsubsection{Number of Participants}

One of the major problems that participants faced when coaching school sport was insufficient numbers of players attending the training schedules. Some players frequently did not attend the training sessions for various reasons in some schools. The players were either punished by schoolteachers or were required to attend make-up classes before the examination. Most coaches were frustrated at having to change their schedules and plans. They were forced to adjust their coaching practice and this might eventually negatively affect coaching outcomes.

[...] insufficient number of players attended my training sessions [which] made me feel frustrated and caused me some problems. Some were punished by 
their teachers and could not come while some did not have [a] good excuse for not attending. The other players were disappointed [...] (Eaton, Interview 2).

[...] the players were not coming for training. They need to attend make-up class or prepare for the test the next day [...] I had to change my coaching plan [...] This influenced the learning of team tactics [...] (Dick, Interview 2).

\subsubsection{Equipment and Facilities}

Some participants felt that inadequate equipment and facilities in schools also influenced their coaching practice. Without appropriate training equipment and facilities, players might have fewer opportunities to learn and practice during training sessions. Schools should provide equipment and facilities to provide a safe coaching environment and assist coaching. In the present study, some coaches reported coaching was affected by limited sport equipment and facilities in schools. The learning of players was negatively affected because of a lack of proper support in some schools.

[...] No proper training hurdle was provided for hurdle event training. The $P E$ teachers told me there was no funding to purchase this training equipment [...] the school training field was not appropriate for training for some track events [...] these problems all influence coaching provision [...] (Gary, Interview 2).

[...] the school did not provide support for the basic equipment and facilities for my training. I was once informed the handball court was being used by another sport's training team [...] Not enough training handballs were available for my players to use in training sessions [...] (Ivan, Interview 2).

\subsubsection{Attitude of Learners}

Players who have an improper learning attitude influence coaching effects. Schools commonly have players with a poor attitude and low effort level. Some participants commented that some players' learning attitude was unsatisfactory. Some players did not make much effort and showed no interest in training. Poor learning attitude from players might threaten the learning atmosphere in the coaching sessions and influence the practice of the coaches.

It is hard to change the learning attitude of players [...] There were more players with improper learning attitudes in recent years. Some players thought they were good enough and did not spend time training [...] their learning attitude influenced the learning atmosphere in the training sessions [...] (Ben, Interview 2).

[...] I was not satisfied with some players as they did not concentrate in training. It was a waste of time if they did not show much effort when practicing [...] their learning attitude in fact influenced my coaching attitude [...] (Adam, Interview 2).

\subsubsection{Weather}

Rainy weather greatly affects sport coach practice in schools. Rainy days are common during spring and summer in Hong Kong. Rain might affect outdoor 
coaching practice. Some participants reported that rain had affected their coaching plans. Unexpected bad weather usually upsets school sport coaches. Most coaches have been forced to modify their training sessions and opted for indoor fitness sessions.

[...] weather is the most challenging issue when I coach the school netball team. I was forced to replace the training with round school running on rainy days $[\ldots]$ afterwards, I added extra training sessions [...] (Cathy, Interview 2).

[...] I could not control the weather [...] bad weather caused me a lot of trouble [...] I replaced the session with land drills and fitness training. This was what I could do during periods of bad weather [...] (Lacy, Interview 2).

\section{Discussion}

The findings of this study correspond with previous studies that have indicated that school sport coaches learn to coach through various coach learning opportunities besides attending formal coach education programmes (Lemyre et al., 2007; Winchester et al., 2013; Wright et al., 2007). However, the participants valued the coaching courses that they attended because the courses provided them with basic knowledge and technical skills necessary for demonstration and planning during coaching practice. This might be because the participants in the study are novice developmental and recreational-level coaches. Young inexperienced coaches usually value formal coach education programmes (Vargas-Tonsing, 2007). They are more confident in coaching after attending the courses because the courses address their learning needs (Lemyre et al., 2007; Meisner \& Danylchuk, 2009; Wright et al., 2007). They gain basic sport coaching knowledge and specific sport techniques and tactics through this formal coach education.

The inexperienced coach participants also emphasised the importance of observing other coaches for starting their coaching career. Through observational learning, the participants learn coaching skills and tactics within a sporting environment (Cushion et al., 2003; Wresch, Law, \& Hall, 2007). They learnt to coach when they were athletes and assistant coaches in the field. Learning by observing experienced peers is regarded as an informal apprenticeship (Sage, 1989). Sage reported that athletes develop an informal impression of coaching by observing the coaching practices of their own coaches. Formal mentoring also provided opportunities for some participants to learn coaching in the present study. Emulating effective mentors could help novice coaches develop coaching styles. Some coaches in the present study benefited from this formal arrangement. Mentoring is often mentioned as an essential method for facilitating coach development (Bloom, Durand-Bush, Schinke, \& Salmela, 1998; Lyle, 2002). Several studies have reported that expert coaches mention mentorship as a key pathway for learning and developing their coaching expertise (Fleurance \& Cotteaux, 1999; Jones, Armour, \& Potrac, 2004). Furthermore, coaches also prefer to receive mentoring when learning sport coaching (Cushion, 2006; Erickson et al., 
2008; Wiersma \& Sherman, 2005).

Moreover, educators have reported that learning can occur through experience and participation in the field (Ben-Peretz, 2002; Wenger, 1998). Research findings have determined that coaches also learn how to coach in this informal learning through personal experience and participation in the sport environment (Cushion et al., 2003; Lemyre et al., 2007). Both playing experience and experience as an assistant coach have been shown to be valuable experience for learning how to coach (Erickson et al., 2008; Lemyre et al., 2007; Sage, 1989; Trudel \& Gilbert, 2006; Wright et al., 2007). Learning through experience is regarded as a necessary component in coach development. Coaches do not simply learn through experience; rather, they develop learning through practice that reflects on experiences (Irwin et al., 2004). Reflecting on experience has been identified as a key mechanism that facilitates learning (Gilbert \& Trudel, 2001; 2005). The participants in the present study agreed that their past sport playing and coaching experience helped their coaching practice. Some coaches evidently reflected on their past experience and improved their coaching ability. In fact, precoaching experience has been reported to be typical of the development of most elite sport coaches (Cregan, Bloom, \& Reid 2007; Gilbert et al., 2006). Hardin (2000) indicated that expert high school coaches draw heavily on their playing experience to demonstrate drills and gain player respect. Athletic experience is seemingly a principal source of coaching knowledge.

The participants also treasured their experience working with others in schools. They stressed that they learnt much by talking to school PE teachers and other school sport coaches. Gilbert and Trudel (2001) reported that youth soccer and ice-hockey coaches solved coaching concerns by interacting with others to ask for advice and jointly construct solutions. Interactions with others is a common method of learning how to coach (Cushion et al., 2003; Erickson et al. 2008; Lemyre et al., 2007). Learning through interactions with others is supported by Wenger's (1998) social theory of learning: learning to coach through communities of practice and legitimate peripheral participation. Coach educators have suggested that interacting with other coaches within communities of practice is a productive approach for promoting coach learning (Culver \& Trudel, 2006; 2008; Trudel \& Gilbert, 2006). School sport coaches continue gaining coaching knowledge through this sustained interaction and learn from one another in the sport environment and workplace.

Most of the coaches in the present study were students studying in PE teacher education programmes. They stated that their education in the PE teacher education programme played a role in their acquisition of coaching knowledge. Coaches reported that they gained knowledge concerning the technical and tactical aspects of their sports from the skills courses of their programmes. Researchers reported that coaches' teacher training in PE contributed to the development of coaching knowledge (Wilson, Bloom, \& Harvey, 2010). Most participants in the present study admitted that their coaching knowledge acquisition 
was related to their learning in university and life experiences as well. Coaching knowledge and teaching skills were learnt from their pedagogy, psychology, and skills courses in the PE teacher education programme.

Hong Kong school sport coaches learn to coach through both mediated and unmediated learning situations (Moon, 2004); they additionally learn how to coach through formal coach education and day-to-day learning experiences in the field (Trudel \& Gilbert, 2006). Both formal coach education and daily life experiences contributed significantly to the development of the coaches in the present study. Therefore, coach education should include all these different learning situations (Wright et al., 2007). Coach educators should provide more opportunities for both mediated and unmediated learning situations for novice coaches and help them to adopt the process of reflection to learn (Trudel \& Gilbert, 2006). Because coaches learn from their daily life experiences, they need ongoing support from their peers and mentors. Studies have determined that coaches benefit and learn through engagement in a community of practice (Bertram, Culver, \& Gilbert, 2016; Culver, Trudel, \& Werthner, 2009; Garner \& Hill, 2017). Coach educators should create communities of practice to provide mentors and communicate with best practices and new ideas for coach development (Culver et al., 2009).

Several contextual factors were identified that influenced the practices of school sport coaches in this study. Insufficient player attendance was frequently mentioned as a major challenge during coaching sessions in schools. The education atmosphere in Hong Kong is the critical factor causing schoolchildren to be less than ideally active in school sport participation. Pang and Ha (2008) reported that parental overemphasis on academic performance was one of the factors that was negatively associated with physical activity engagement among Hong Kong children. The examination-oriented education system in Hong Kong forces parents and schoolchildren to focus on activities that are related to subjects that are assessed in schools. The disproportionate importance given to academic achievements among Chinese families is rooted in Confucian educational philosophy. Balancing academic and other responsibilities and activities with sports participation is a challenge for some players. Schoolchildren might be pressured by their parents into withdrawing from sport (Pang \& Ha, 2008). Improving communication among parents, schoolteachers, and players and strengthening the coach-player-parent relationship might help players to participate in school training sessions (Knight \& Holt, 2013; Smoll, Cumming, \& Smith, 2011). Apart from providing quality coach practice and a positive experience to attract more players to continue sport participation, school sport coaches should consider the academic progress and personal development of each player as well. They may consider helping players maintain a healthy balance between academic studies and sports training (Cruz, 2014).

The school training environment can be a key factor influencing the quality and quantity of school sport activities. Specifically, in Hong Kong, limited activ- 
ity space and equipment can affect sport participation levels. Schools that lack outdoor facilities and related sport equipment tend to provide limited opportunities for sport participation among schoolchildren. The weather (in particular, rain and humidity) may also influence whether school sport training is offered. Lacking resources has been mentioned as a major challenge experienced by sport coaches (Baltzell et al., 2014; Chroni, Diakaki, Perkos, Hassandra, \& Schoen, 2013; Fortuin \& Coopoo, 2012; Kubayi, Coopoo, \& Morris-Eyton, 2015). This finding was observed in the present study. This implies that the facilities and equipment provided by school administrators have considerable room for improvement. Coach educators should help novice school coaches understand school coaching environments and to be able to handle these difficulties during coaching. School sport coaches are advised to work proactively and closely with school administrators and PE teachers to settle their concerns to provide quality coaching practices in schools.

Several limitations affected the present study and the data. First, the small sample size of the participants might not accurately reflect the learning and practice of school sport coaches in Hong Kong. They are not representative of Hong Kong school sport coaches as a whole and therefore it generalising the results may be difficult. Second, the participants are not a random sample of coaches; rather, coaches were selected based on snowball sampling and volunteered to participate in the present study. Bias among those who chose to reply to the email and showed interest in participating in the study may be present; this might make the participants dissimilar from those who did not reply. Third, participants were mainly from one tertiary education institution, which potentially limited the learning and coaching practices in their schools and influenced the results. Furthermore, the interviews that occurred in the present study focused solely on the coaches' perceptions; the viewpoints of players, PE teachers, parents, and school administrators were not considered or examined. Nevertheless, this study did provide information about how school sport coaches learn to coach and the factors that influence coaching practice in schools. However, from a practical perspective, this study may be beneficial to coach educators and school sport coaching professionals and may help to train novice school sport coaches for practice in schools. For future research, increasing the sample size of participants, observing coaches' practices in schools, and collecting views from players and $\mathrm{PE}$ teachers is recommended to obtain a comprehensive picture of how school coaches learn to practice and understand their contextual limitations when coaching. Further research is also needed to examine how school sport coaches in other countries learn how to coach and understand their constraints.

\section{Conclusion}

The present study explored how school sport coaches learn to coach and the factors influencing their practices in schools. The results of this study highlight that school sport coaches learn to coach through formal coach education pro- 
grammes and in various informal settings. The processes by which school sport coaches develop and learn to coach are ongoing and occur within separate individuals' daily life experiences. School sport coaches learn to coach through different learning situations throughout their lifespans and this is a lifelong development process. All these learning situations are valuable and vital to a coach's learning and development. Coach education programmes should equip young coaches with knowledge regarding self-reflection. They should use the self-reflection process in different learning situations for further learning and development of their coaching practices. Furthermore, the findings of the study also indicate that some local contextual factors limit the practices of school coaches in Hong Kong. School coaches should work closely with school teachers, school administrators, and parents to provide quality training environments for players.

\section{References}

Baltzell, A. L., McCarthy, J. M., Ahktar, V. L., Hurley, D., Martin, I., \& Bowman, C. (2014). High School Coaches' Sources of Joy and Unhappiness. Journal of Multidisciplinary Research, 6, 5-24.

Bell, M. (1997). The Development of Expertise. Journal of Physical Education Recreation and Dance, 68, 34-38. https://doi.org/10.1080/07303084.1997.10604893

Ben-Peretz, M. (2002) Retired Teachers Reflect on Learning from Experience. Teachers and Teaching: Theory and Practice, 8, 313-323. https://doi.org/10.1080/135406002100000468

Bertram, R., Culver, D., \& Gilbert, W. (2016). Creating Value in a Sport Coach Community of Practice: A Collaborative Inquiry. International Sport Coaching Journal, 3, 2-16. https://doi.org/10.1123/iscj.2014-0122

Bloom, G. A., Durand-Bush, N., Schinke, R. J., \& Salmela, J. H. (1998). The Importance of Mentoring in the Development of Coaches and Athletes. International Journal of Sport Psychology, 29, 267-281.

Braun, V., \& Clarke, V. (2006). Using Thematic Analysis in Psychology. Qualitative Research in Psychology, 3, 77-101. https://doi.org/10.1191/1478088706qp063oa

Carter, A. D., \& Bloom, G. A. (2009). Coaching Knowledge and Success: Going beyond Athletic Experiences. Journal of Sport Behavior, 32, 419-437.

Chroni, S. A., Diakaki, E., Perkos, S., Hassandra, M., \& Schoen, C. (2013). What Stresses Coaches in Competition and Training? An Exploratory Inquiry. International Journal of Coaching Science, 7, 25-39.

Cregan, K., Bloom, G. A., \& Reid, G. (2007). Career Evolution and Knowledge of Elite Coaches of Swimmers with a Physical Disability. Research Quarterly for Exercise and Sport, 78, 339-350. https://doi.org/10.1080/02701367.2007.10599431

Creswell, J. (2007). Qualitative Inquiry \& Research Design: Choosing among Five Approaches. London: Sage.

Cruz, A. (2014). The Coaching Behaviours and Philosophy of High Performance Secondary School Basketball Coaches. Asian Journal of Physical Education \& Recreation, 20, 21-38.

Cruz, A., Li, C., \& Kam, W. K. (2009). Coaching Beliefs and Behaviours of High Performance High School Basketball Coaches. Paper Presented at International Congress in 
Sports Psychology, Gwalior.

Culver, D. M., Trudel, P., \& Werthner, P. (2009). A Sport Leader's Attempt to Foster a Coaches' Community of Practice. International Journal of Sports Science \& Coaching, 4, 365-383. https://doi.org/10.1260/174795409789623900

Culver, D., \& Trudel, P. (2006). Cultivating Coaches' Communities of Practice: Developing the Potential for Learning through Interactions. In R. L. Jones (Ed.), The Sports Coach as Educator: Re-Conceptualising Sports Coaching (pp. 97-112). London: Routledge.

Culver, D., \& Trudel, P. (2008). Clarifying the Concept of Communities of Practice in Sport: A Response to Commentaries. International Journal of Sports Science \& Coaching, 3, 29-32. https://doi.org/10.1260/174795408784089388

Cushion, C. (2006). Mentoring: Harnessing the Power of Experience. In R. L. Jones (Ed.), The Sports Coach as Educator: Re-Conceptualising Sports Coaching (pp. 128-144). London: Routledge.

Cushion, C. J., Armour, K. M., \& Jones, R. L. (2003). Coach Education and Continuing Professional Development: Experience and Learning to Coach. Quest, 55, 215-230. https://doi.org/10.1080/00336297.2003.10491800

Erickson, K., Bruner, M. W., Macdonald, D. J., \& Côté, J. (2008). Gaining Insight into Actual and Preferred Sources of Coaching Knowledge. International of Sports Science \& Coaching, 3, 527-538. https://doi.org/10.1260/174795408787186468

Fleurance, P., \& Cotteaux, V. (1999). Construction de l'expertise chez les entraineurs sportifs d'athletes de haut-niveau francais. [Development of Expertise in Elite Athletic Coaches in France.] Avante, 5, 54-68.

Fortuin, C. S., \& Coopoo, Y. (2012). The Management of Youth Football Development Programmes in Gauteng, South Africa. African Journal for Physical, Health Education, Recreation and Dance, 2, 73-84.

Garner, P., \& Hill, D. H. (2017). Cultivating a Community of Practice to Enable Coach Development in Alpineski Coaches. International Sport Coaching Journal, 4, 63-75. https://doi.org/10.1123/iscj.2016-0076

Gilbert, W., \& Trudel, P. (2001). Learning to Coach through Experience: Reflection in Model Youth Sport Coaches. Journal of Teaching in Physical Education, 21, 16-34. https://doi.org/10.1123/jtpe.21.1.16

Gilbert, W., \& Trudel, P. (2005). Learning to Coach through Experience: Conditions That Influence Reflection. Physical Educator, 62, 32-43.

Gilbert, W., Côté, J., \& Mallett, C. (2006). The Talented Coach: Developmental Paths and Activities of Successful Sport Coaches. International Journal of Sports Science and Coaching, 1, 69-76. https://doi.org/10.1260/174795406776338526

Ha, J. P., Hums, M. A., \& Greenwell, T. C. (2011). Dual Role of Physical Education Teacher-Athletic Directors in Korean Secondary School. Physical Educator, 68, 221-233.

Hardin, B. (2000). Coaching Expertise in High School Athletics: Characteristics of Expert High School Coaches. Applied Research in Coaching and Athletics Annual, 15, 24-38.

Irwin, G., Hanton, S., \& Kerwin, D. (2004). Reflective Practice and the Origins of Elite Coaching Knowledge. Reflective Practice, 5, 425-442. https://doi.org/10.1080/1462394042000270718

Jarvis, P. (2006). Towards a Comprehensive Theory of Human Learning. New York, NY: Routledge.

Jones, R. L., Armour, K. M., \& Potrac, P. (2003). Constructing Expert Knowledge: A Case 
Study of a Top Level Professional Soccer Coach. Sport, Education, and Society, 8, 213-229. https://doi.org/10.1080/13573320309254

Jones, R. L., Armour, K. M., \& Potrac, P. (2004). Sports Coaching Cultures: From Practice to Theory. London: Routledge.

Kirk, D. (2010). Towards a Socio-Pedagogy of Sports Coaching. In J. Lyle, \& C. Cushion (Eds.), Sports Coaching Professionalization and Practice (pp. 165-176). London: Elsevier.

Knight, C. J., \& Holt, N. L. (2013). Strategies Used and Assistance Required to Facilitate Children's Involvement in Competitive Tennis: Parents' Perspectives. The Sport Psychologist, 27, 281-291. https://doi.org/10.1123/tsp.27.3.281

Kubayi, N. A., Coopoo, Y., \& Morris-Eyton, H. F. (2015). Challenges Faced by Sport Coaches in South Africa. African Journal for Physical, Health Education, Recreation and Dance, 21, 724-732.

Lacroix, C., Camiré, M., \& Trudel, P. (2008). High School Coaches' Characteristics and Their Perspectives on the Purpose of School Sport Participation. International Journal of Coaching Science, 2, 23-42.

Lemyre, F., \& Trudel, P. (2004). Le parcours d'apprentissage au rôle d'entraîneur bénévole. [The Learning Path of Volunteer Coaches.] Avante, 10, 40-55.

Lemyre, F., Trudel, P., \& Durand-Bush, N. (2007). How Youth Sport Coaches Learn to Coach. Sport Psychologist, 21, 191-209. https://doi.org/10.1123/tsp.21.2.191

Lyle, J. W. B. (2002). Sports Coaching Concepts: A Framework for Coaches' Behavior. London: Routledge.

Meisner, K., \& Danylchuk, K. (2009). Coaches' Perceptions of Canada's National Coaching Certification Program (NCCP): Awareness and Value. International Journal of Sports Science and Coaching, 4, 233-243. https://doi.org/10.1260/174795409788549580

Merriam, S. (2009). Qualitative Research: A Guide to Design and Implementation. San Francisco, CA: Jossey-Bass.

Miles, M. B., \& Huberman, A. M. (2014). Qualitative Data Analysis: A Methods Sourcebook. Thousand Oaks, CA: Sage.

Moon, J. A. (1999). Reflection in Learning and Professional Development: Theory and Practice. New York, NY: Psychology Press.

Moon, J. A. (2001). Short Courses and Workshops: Improving the Impact of Learning, Training and Professional Development. London: Kogan Page.

Moon, J. A. (2004). A Handbook of Reflective and Experiential Learning: Theory and Practice. London: Routledge Falmer.

Pang, B. O. H., \& Ha, A. S. C. (2008). Parental Concerns in Facilitating Children's Physical Activity Participation in Hong Kong. Journal of Physical Education and Recreation (Hong Kong), 14, 39-46.

Patton, M. Q. (2002). Qualitative Research and Evaluation Methods (3rd ed.). Thousand Oaks, CA: Sage.

Pope, J. P., Stewart, N. W., Law, B., Hall, C. R., Gregg, M. J., \& Robertson, R. (2014). Knowledge Translation of Sport Psychology to Coaches: Coaches' Use of Online Resources. International Journal of Coaching Science, 10, 1055-1070. https://doi.org/10.1260/1747-9541.10.6.1055

Sage, G. (1989). Becoming a High School Coach: From Playing Sports to Coaching. Research Quarterly for Exercise and Sport, 66, 81-92. https://doi.org/10.1080/02701367.1989.10607417 
Smoll, F. L., Cumming, S. P., \& Smith, R. (2011). Enhancing Coach-Parent Relationships in Youth Sports: Increasing Harmony and Minimizing Hassle. International Journal of Sports Science \& Coaching, 6, 13-26. https://doi.org/10.1260/1747-9541.6.1.13

Spencer, A. (1999). A Case Study of an Exemplary American College Physical Educator Tennis Coach. Journal of Sport Pedagogy, 5, 1-27.

Trudel, P., \& Gilbert, W. (2006). Coaching and Coach Education. In D. Kirk, D. Macdonald, \& M. O'Sullivan (Eds.), The Handbook of Physical Education (pp. 516-539). London: Sage. https://doi.org/10.4135/9781848608009.n29

Trudel, P., Culver, D., \& Werthner, P. (2013). Looking at Coach Development from the Coach-Learner's Perspective: Consideration for Coach Development Administrators. In P. Potrac, W. Gilbert, \& J. Denison (Eds.), Routledge Handbook of Sports Coaching (pp. 375-387). London: Routledge.

Vargas-Tonsing, T. M. (2007). Coaches' Preferences for Continuing Coaching Education. International Journal of Sports Science \& Coaching, 2, 25-35. https://doi.org/10.1260/174795407780367186

Wenger, E. (1998). Communities of Practice: Learning, Meaning, and Identity. New York, NY: Cambridge University Press. https://doi.org/10.1017/CBO9780511803932

Werthner, P., \& Trudel, P. (2006). A New Theoretical Perspective for Understanding How Coaches Learn to Coach. Sport Psychologist, 2, 198-212. https://doi.org/10.1123/tsp.20.2.198

Wiersma, L. D., \& Sherman, C. (2005). Volunteer Youth Sport Coaches' Perspectives of Coaching Education/Certification and Parental Codes of Conduct. Research Quarterly for Exercise and Sport, 76, 324-338. https://doi.org/10.1080/02701367.2005.10599303

Wilson, L. M., Bloom, G. A., \& Harvey, W. J. (2010). Sources of Knowledge Acquisition: Perspectives of the High School Teacher/Coach. Physical Education and Sport Pedagogy, 18, 383-399. https://doi.org/10.1080/17408980903273154

Winchester, G., Culver, D., \& Camiré, M. (2013). Understanding How Ontario High School Teacher-Coaches Learn to Coach. Physical Education and Sport Pedagogy, 15, 412-426. https://doi.org/10.1080/17408989.2012.690376

Wresch, N. N., Law, B., \& Hall, C. R. (2007). The Use of Observational Learning by Athletes. Journal of Sport Behavior, 30, 219-231.

Wright, T., Trudel, P., \& Culver, D. (2007). Learning How to Coach: The Different Learning Situations Reported by Youth Ice Hockey Coaches. Physical Education and Sport Pedagogy, 12, 1-17. https://doi.org/10.1080/17408980701282019 